\title{
Integrated Modeling of Soil Erosion for a Canadian Watershed in Response to Projected Changes in Climate and Consequent Adoption of Mitigating Best Management Practices
}

\author{
Robert L. France*, Chengxi Zhang, Gordon R. Brewster \\ Department of Plants, Food and Environmental Science, Faculty of Agriculture, Dalhousie University, Truro, Canada \\ Email: *rfrance@dal.ca
}

How to cite this paper: France, R.L., Zhang, C.X. and Brewster, G.R. (2018) Integrated Modeling of Soil Erosion for a Canadian Watershed in Response to Projected Changes in Climate and Consequent Adoption of Mitigating Best Management Practices. Journal of Geoscience and Environment Protection, 6, 12-34.

https://doi.org/10.4236/gep.2018.66002

Received: January 22, 2018

Accepted: June 12, 2018

Published: June 15, 2018

Copyright $\odot 2018$ by authors and Scientific Research Publishing Inc. This work is licensed under the Creative Commons Attribution International License (CC BY 4.0).

http://creativecommons.org/licenses/by/4.0/

\section{(c) (i) Open Access}

\begin{abstract}
Controlling soil erosion and the transport and deposition of suspended sediment to receiving waters, especially in relation to the modifying influences of, and interplay between, climate and land-use alterations, is essential for effective watershed management. The Atlantic Canada-New England region is expected to experience elevated rainfall erosivity due to climate change over the next century. Using the projected higher precipitation amounts of $5 \%$ and $10 \%$ for future scenarios of 5 and 25 years for the region, and a spatially-explicit, integrated (GIS, RUSLE) model for a rural watershed in Nova Scotia, predicted increases in total erosion rates of 4.9 and 9.9\%, respectively. Modelled scenarios altering buffer strips based on either consistent or slope-variable widths between $30 \mathrm{~m}$ (the legal requirement) to 90 $\mathrm{m}$ were found to correspond to reductions in predicted total watershed erosion rates from $11 \%$ to $32 \%$. Assuming and extending the $1: 1$ concordance between projected precipitation and estimated soil erosion for this particular watershed into the more distant future of 26 to 55 years, suggests that the $25 \%$ increase in soil erosion predicted over this period would have to be offset by expanding the protective buffer strips to a consistent width of $70 \mathrm{~m}$. Adoption of such a protective management scheme would subsume $19 \%$ of the terrestrial area of the study watershed and thus consequent reductions in land available for agricultural production and timber harvest.
\end{abstract}

\section{Keywords}

Watershed Soil Erosion, Integrated (GIS, RUSLE) Modelling, Climate Change, Buffer Strips 


\section{Introduction}

Understanding the interplay between climate and land-use management factors related to soil erosion is essential to achieving the long-term sustainable management of forested and agricultural ecosystems [1]. Controlling soil erosion and the transport and deposition of suspended sediment to receiving waters is recognized as being one of the most important tools of effective watershed management [2] [3]. In particular, because phosphorus can be transported through movement of soil particles, and because it is often the element limiting freshwater productivity, predictions of potential erosion and thus nutrient export are critical for managing aquatic eutrophication [4].

Soil erosion rates are susceptible to changes in climate, in particular to alterations in rainfall [5] [6] [7] [8] [9], due to the erosive force of rain being directly related to both surface and interrill erosion [10] [11]. But climate alone is of course not the sole determinant of the mechanisms and magnitude of soil erosion. This is because many of those watersheds in which we are most interested in predicting erosion are also those that are characterized by the presence of human activity. It is therefore essential to understand how changes in regional climate act either in synergy or in opposition to local landscape modifications. For, as Hatfield and Prueger [8] aptly phrase it, "Changing precipitation patterns and intensity under climate change scenarios could have a major impact on the response of various management practices." One example of this is Blais et al.'s [12] study of sediment deposition rates in northwestern Ontario lakes. Here the authors determined that the effects of regional drought on decreasing erosion completely superseded any increases in erosion brought about by forestry operations (watershed clearcutting and road construction), thereby moderating the potential deleterious impacts of the latter. But in those regions where climate change models predict increases rather than decreases in rainfall, and thus predict elevated soil erosivity, it is meritorious to exhibit heightened concern about the long-term health of aquatic resources due to the potential for acerbating problems already ensuing from possibly less-than-perfect practices of land-use management. In such cases, there will be a need to implement best management practices (BMPs) in order to ensure the protection of aquatic integrity.

Few BMPs deliver more ecosystem goods and services per unit areal coverage than do riparian buffer strips [13] [14], particularly in relation to reducing the transport and deposition of soil to otherwise threatened lakes and rivers, such as those in Canada [10] [15] [16] [17]. There exists a great variability in jurisdictional recommendations of buffer strip design and management [18] [19] [20], including in Canada [15] [21] [22]. Specifically, management practices concerning vegetated riparian buffers have been the subject of recent studies in Atlantic Canada [23] [24] [25] [26]. In a comprehensive review, Capron et al. [27] identify riparian ecosystems as being those landscapes that will be in particular need for adapting human activities in the face of climate change. One obvious 
land-use decision that needs to be considered, therefore, for Atlantic Canada and elsewhere, concerns whether existing recommendations about the width of protective buffer strips will have to be reexamined in order to mitigate the threat of increased erosion predicted for certain regions under the auspices of climate change.

Models of soil erosion in response to climate change predictions have existed for more than a decade [28] [7]. And these have been undertaken on different scales of resolution, ranging from regions [5], to large areas [6], to specific locations on simulated landscape typologies [29]. One of the most useful approaches in comprehensive nutrient management planning on a watershed scale has proven to be the geo-spatial application of erosion models through geographic information system (GIS) analyses [30] [31]. In particular, the integration of the long established and revised universal soil loss equation (RUSLE) with spatially explicit mapping through GIS analysis promises to generate the most accurate predictions of soil erosion for watersheds [32] [33] [34].

The Atlantic Canada-New England bioregion is predicted to experience increases in rainfall erosivity consequent with climate change over the next century [5]. Further, due to presence of a thin glacial overburden of easily dislodged soils, lakes and rivers in these watersheds are sensitive to a variety of anthropogenic landscape disturbances [35] [36] [37]. This has led to a growing number of geo-spatial and modelling studies of soil erosion and nutrient export in the region [38]-[44].

The purpose of the present study was to investigate potential changes in the magnitude of soil erosion for a small watershed in Nova Scotia, Canada in response to alterations in climate (precipitation amount) and land-use management (buffer strip allocation) through use of an integrated, spatially-explicit model based on application of the RUSLE and GIS analysis.

\section{Materials and Methods}

\section{Study Area}

We applied climate change projections of altered annual precipitation and of hypothesized land-use alterations of buffer strip widths to the North River watershed located at the head of the Bay of Fundy in the Colchester County region of north-central Nova Scotia. The North River drains into the Salmon River, which flows into Cobequid Bay near Old Barns (Figure 1 \& Figure 2). The combined watershed area of the North and Salmon Rivers is $740 \mathrm{~km}^{2}$ [45], of which 35\% had been deforested by the year 2000 [46] (Figure 3). The North River (Figure 4) flows $30 \mathrm{~km}$ from its headwaters to the tidal outlet near the joint cities of Truro and Bible Hill, which have a combined population of about twenty thousand. The watershed has a shallow gradient in that there is only a $310 \mathrm{~m}$ difference in elevation along the complete length of the stream network. Riparian slopes are also gentle, with an overall mean surface slope of $9 \%$ and the large majority being less than $15 \%$. Until about a quarter of a century ago, forests 


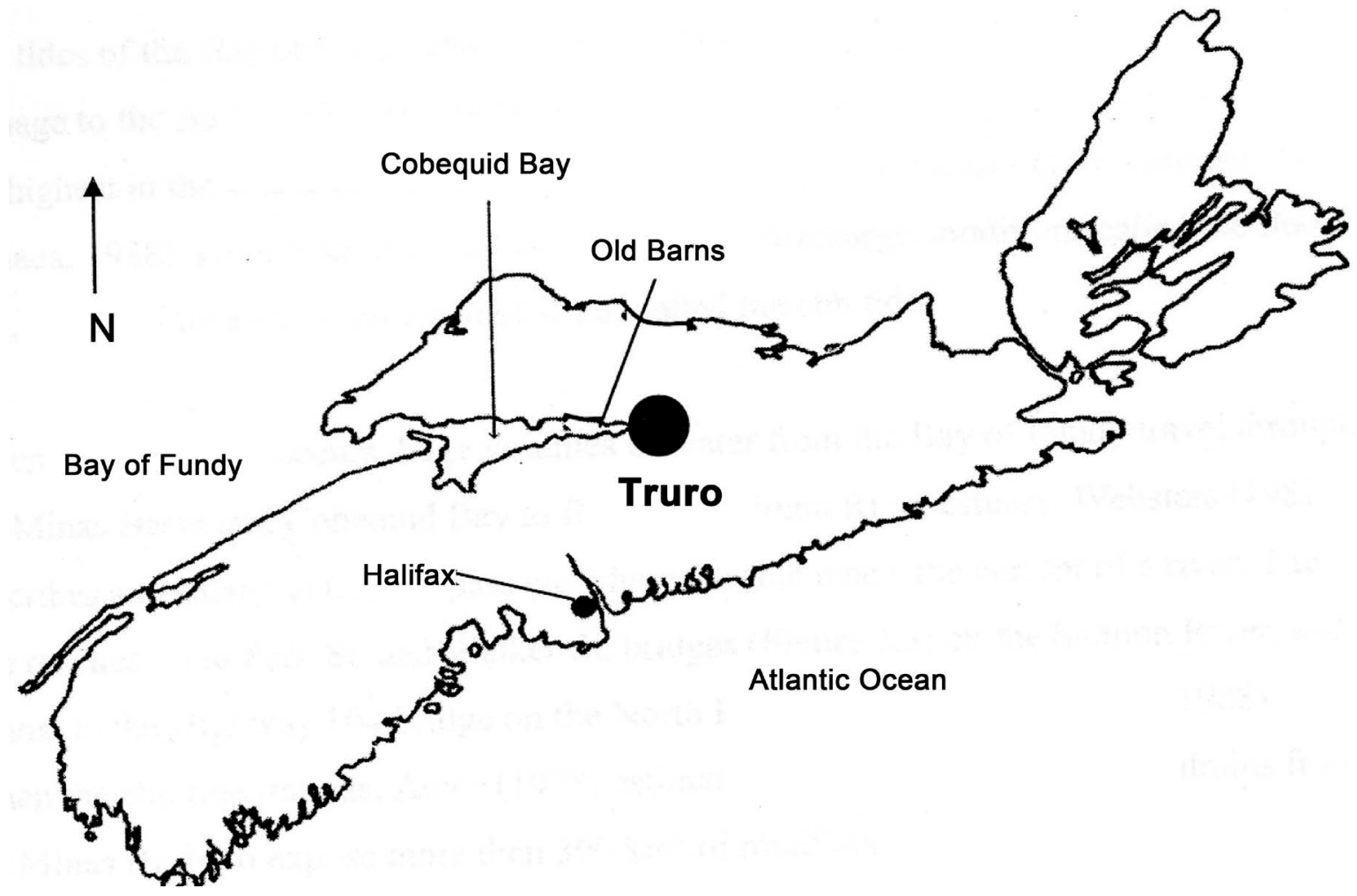

Figure 1. Province of Nova Scotia and study area of North River watershed, latitude $45.4^{\circ} \mathrm{N}$; longitude $63.3^{\circ} \mathrm{W}$. Source: [46].

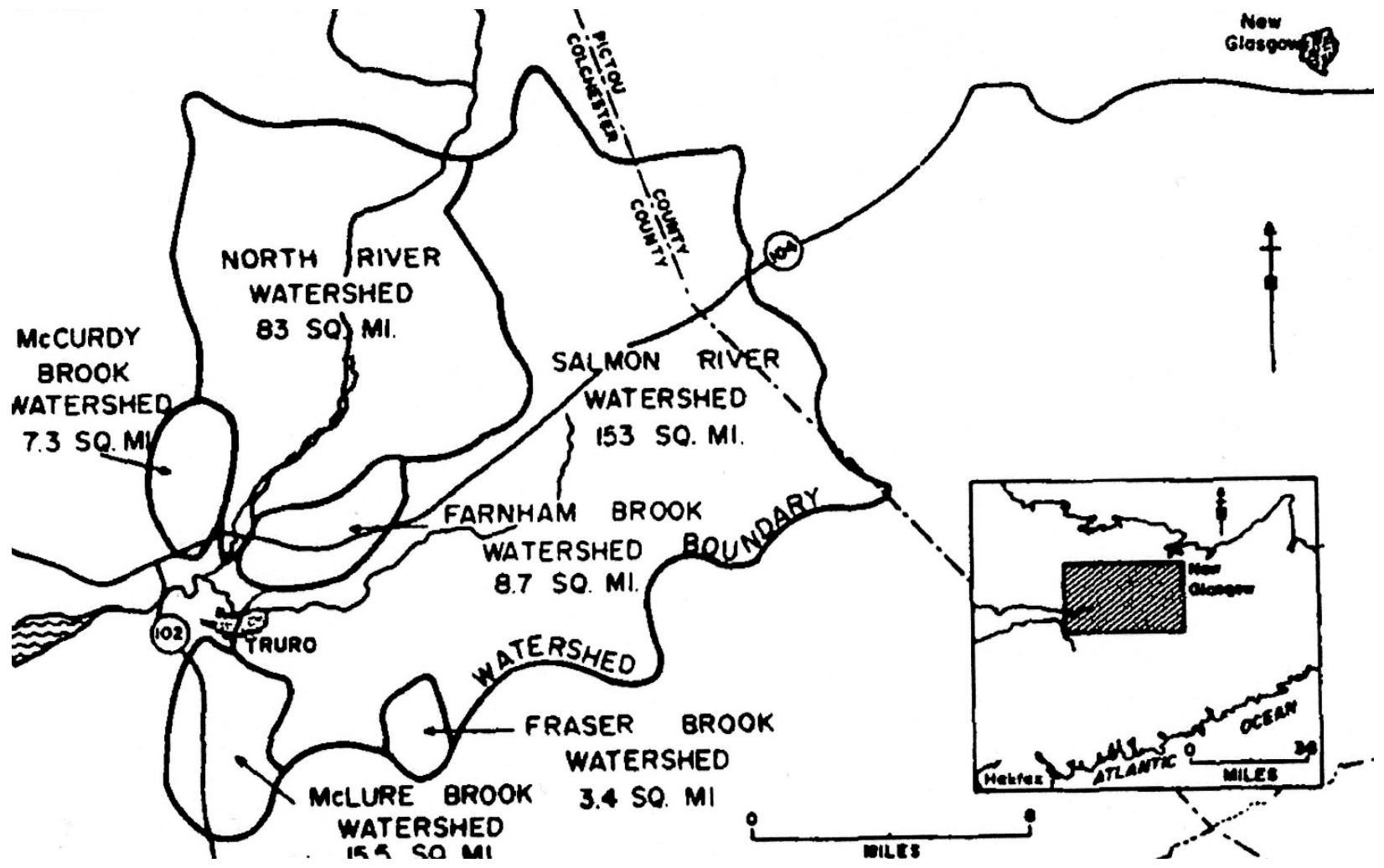

Figure 2. Combined watershed of the North and Salmon Rivers (including associated subwatersheds) in Colchester Country, Nova Scotia. Source: [46]. 


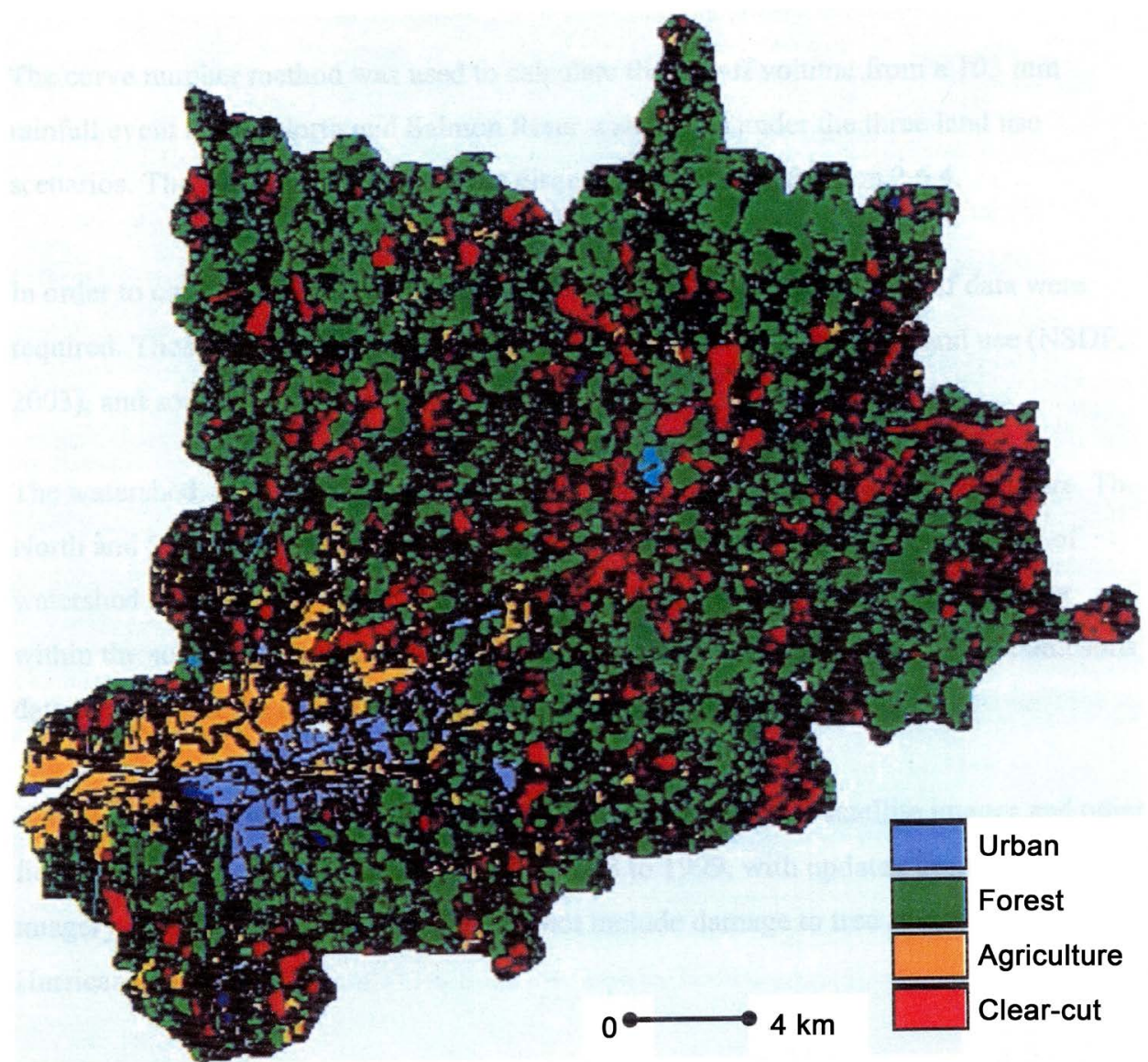

Figure 3. Land use conditions of the combined North and Salmon Rivers watershed in the year 2000. Source: [46]. Since that time, urbanization, agriculture, and deforestation have spread significantly in the lower, middle, and upper portions of the watershed, respectively.

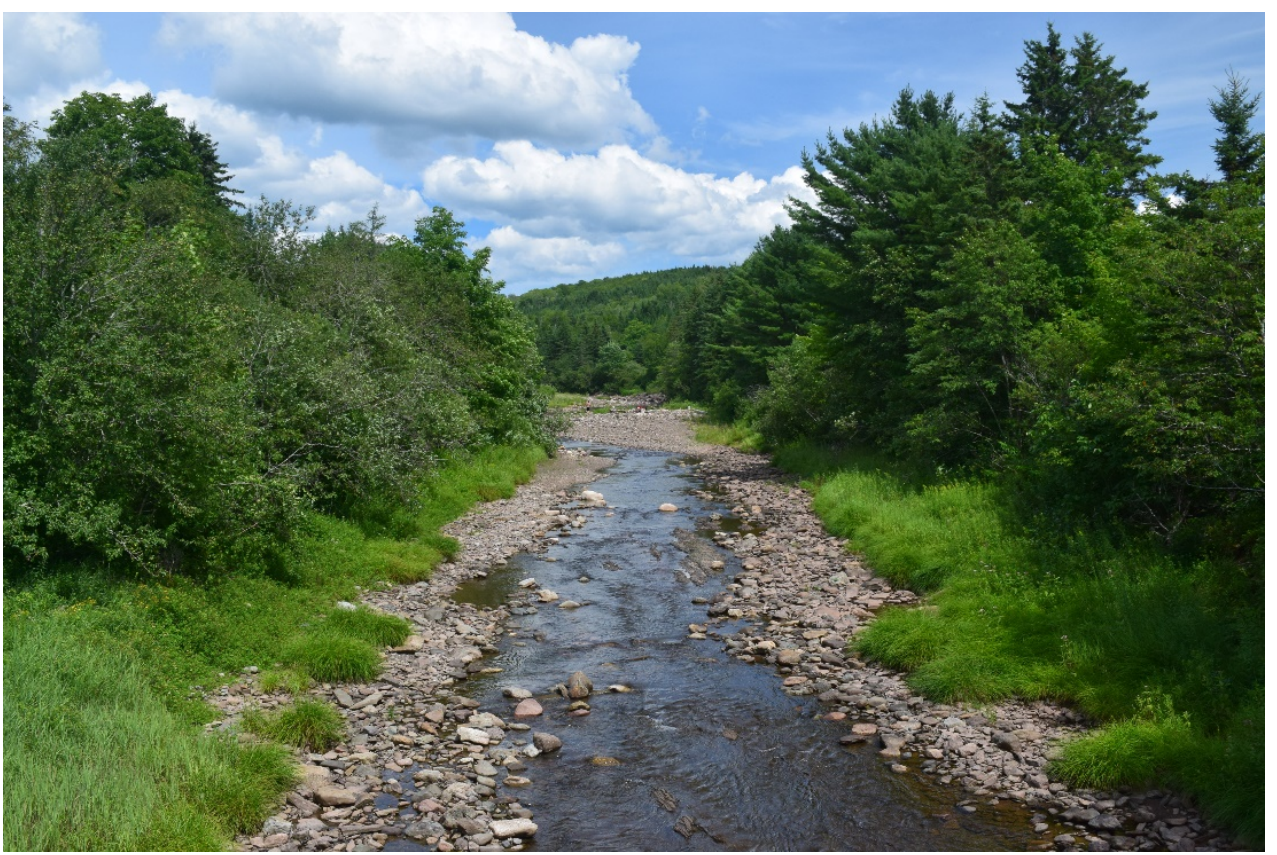




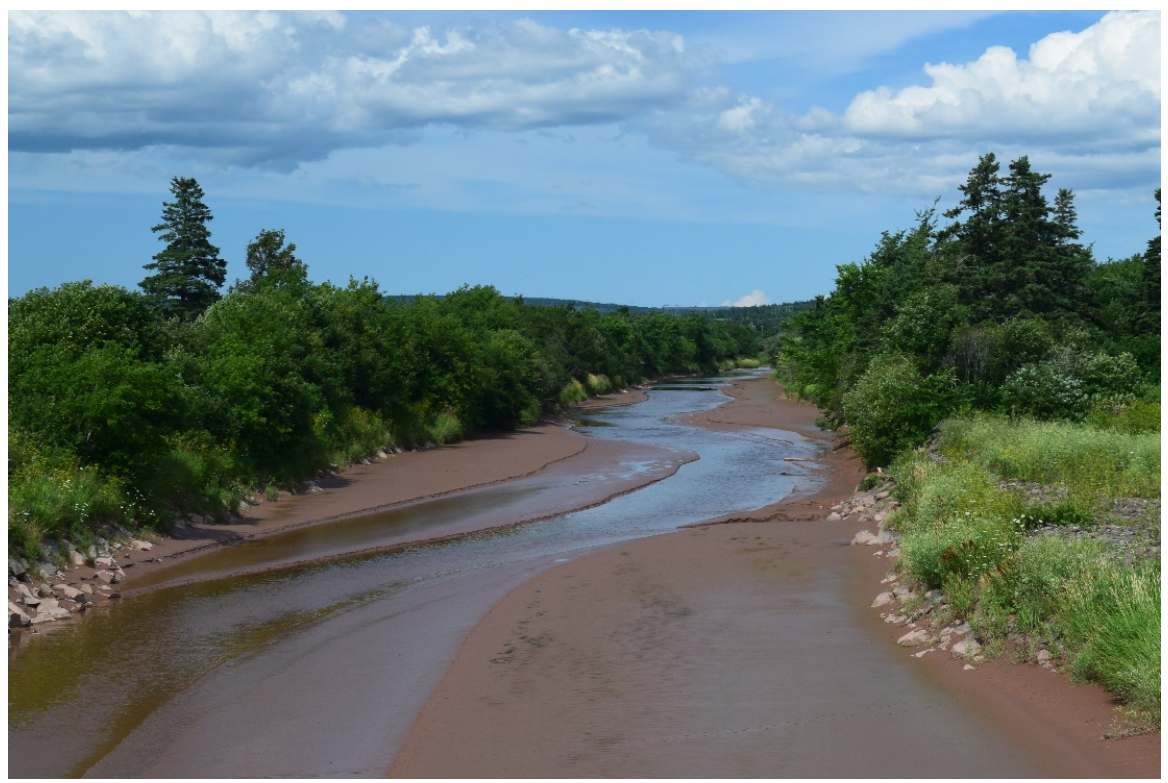

Figure 4. Representative images of the North River, Colchester County, Nova Scotia from its upper reaches and tidally influenced lower reaches.

accounted for $80 \%$ of the land cover in the North River watershed, dominated by softwoods (spruces and firs), followed by hardwoods (maples), and mixed stands [47]. Since then, the extent of forest cover has decreased, with $60 \%$ of the total land area now being sylvan [O'Brien, T. Nova Scotia Dept. Natural Resources, unpubl. data, 2015] (Figure 5), coincident with a reciprocal increase in the extent of agricultural land in the mid and lower watershed (now 30\% surface area; Figure 6), and urbanization (now 10\% surface area) in the lower watershed. Peri-urban agricultural land is being targeted for future housing development (Figure 7).

Zhang [48] conducted a preliminary investigation of the regional susceptibility for erosion for Colchester County, as determined through GIS analysis [48] (Table 1; Figure 8). The purpose of the present study was to follow-up on this earlier work by zooming into one particular section of the County, the North River watershed, in order to specifically model the effects of simulated climate change and land use modification on estimated soil erosion rates. The North River watershed was selected in this regard due to it being the subject of extensive study in terms of its hydrology ([45] [46] and more than a dozen government "gray literature" reports cited therein) and soil characteristics [47]. The soil parent material is glacially derived, with clay till, sandy till, and glaciofluvial sands and gravels, covering, respectively, $50 \%, 30 \%$, and $20 \%$ of the surface area. All upland soils are regarded as podzols.

Colchester County, Nova Scotia is considered to be have a humid and temperate continental climate, moderated by proximity of the ocean. The North River watershed receives $696 \mathrm{~mm}$ of precipitation a year (monthly mean of $58 \mathrm{~mm}$ ), of which $298 \mathrm{~mm}$ occurs as rain during the months of May to October (mean for 

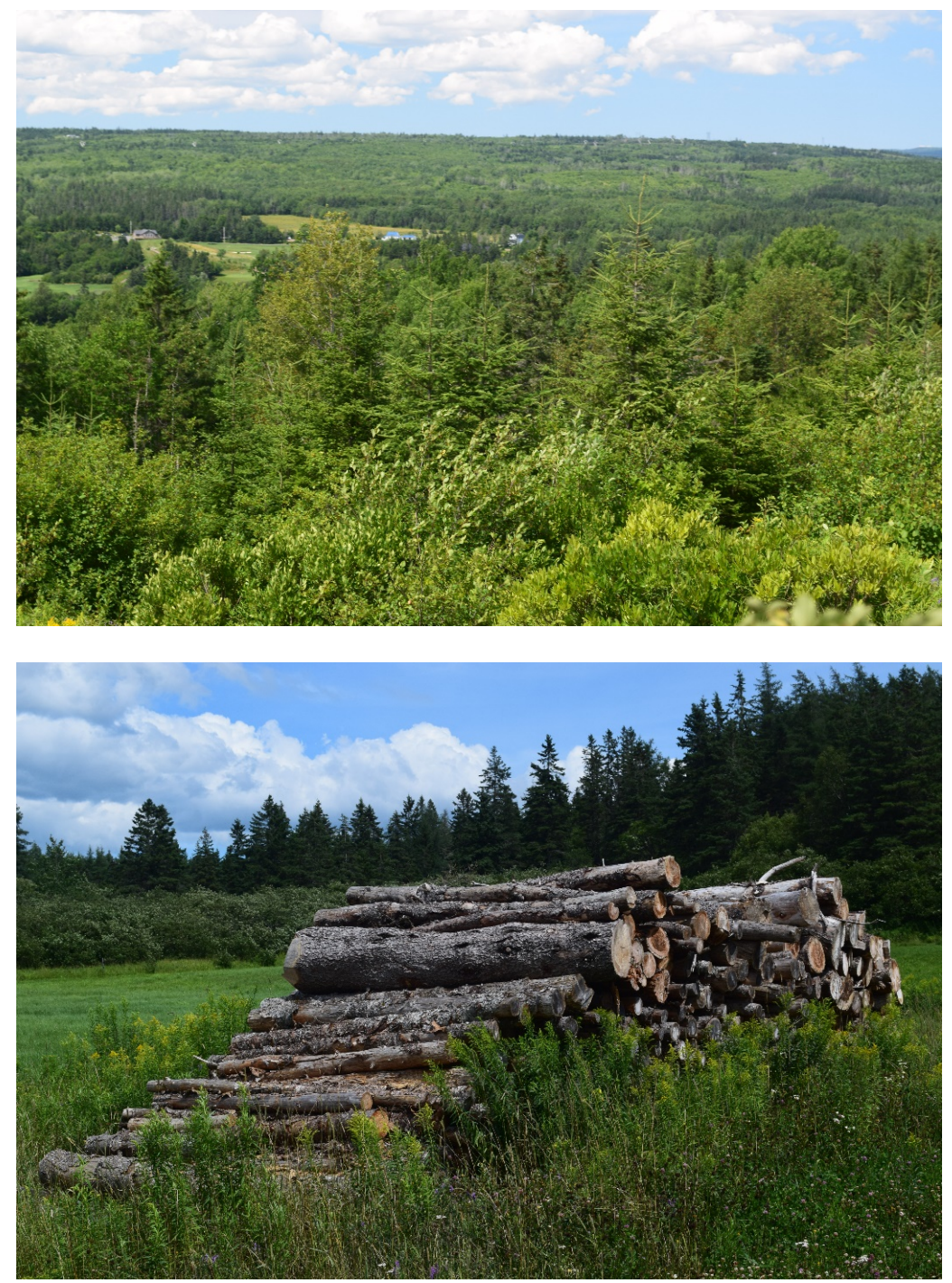

Figure 5. Forests and forestry operations in the upper watershed of the North River, Colchester County, Nova Scotia.

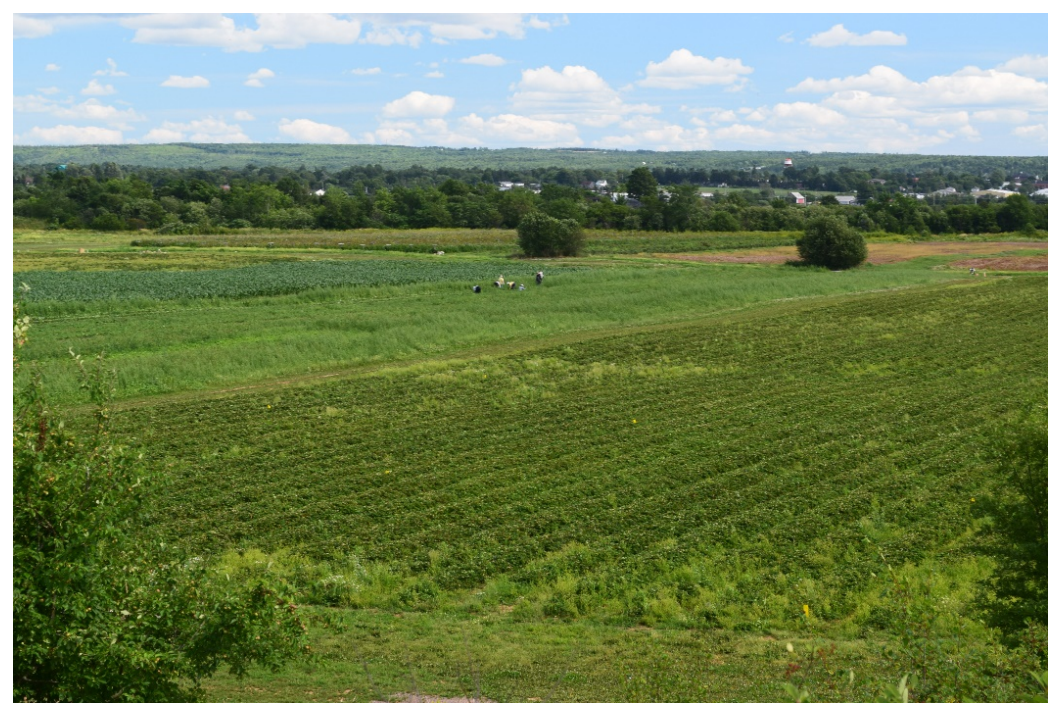




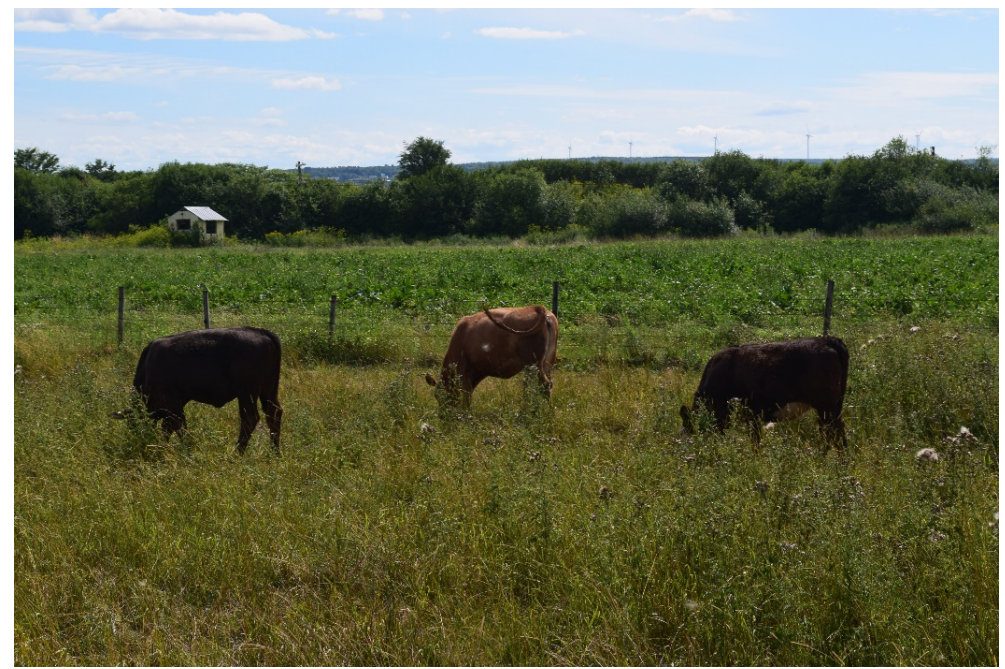

Figure 6. Agriculture in the mid and lower watershed of the North River, Colchester County, Nova Scotia.
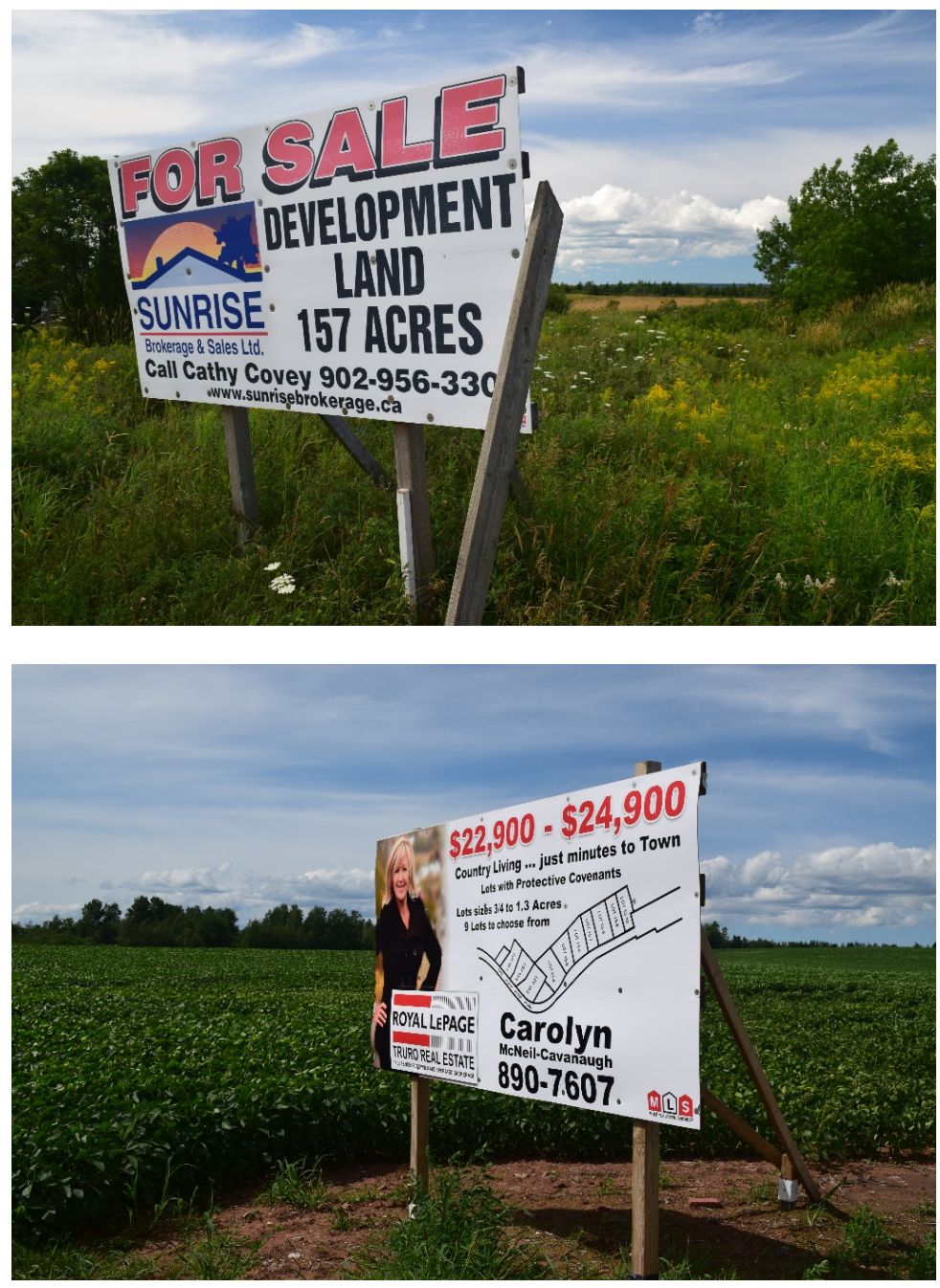

Figure 7. Peri-urban agricultural land zoned for development near the cities of Truro-Bible Hill in the lower watershed of the North River, Colchester County, Nova Scotia. 
Table 1.Classification of soil erosion rates for Colchester County, Nova Scotia. See Figure 8. Source: [48].

\begin{tabular}{ccc}
\hline Erosion Class & Soil erosion rate (tons $/ \mathrm{km}^{2} /$ year) & Erosion potential \\
\hline 1 & $0.5-15.8$ & No susceptibility \\
2 & $15.8-39.6$ & Very low susceptibility \\
3 & $39.6-77.8$ & Low susceptibility \\
4 & $77.8-148.5$ & Medium to low susceptibility \\
5 & $148.5-285.5$ & Medium susceptibility \\
6 & $285.5-478.1$ & Medium to high susceptibility \\
7 & $478.1-750.5$ & High susceptibility \\
8 & $750.5-1372.0$ & Very high susceptibility \\
\hline
\end{tabular}

\section{Soil loss rate (tons $/ \mathrm{km}^{2} /$ year)}

\section{Soil_erosion_map}

Class 1 No susceptibility (light yellow)

Class 2 Very low susceptibility (yellow/orange)

Class 3 Low susceptibility (light orange)

Class 4 Medium to low susceptibility (medium orange)

Class 5 Medium susceptibility (dark orange)

Class 6 Medium to high susceptibility (orange/red)

Class 7 High susceptibility (red)

Class 8 Very high susceptibility (dark red)
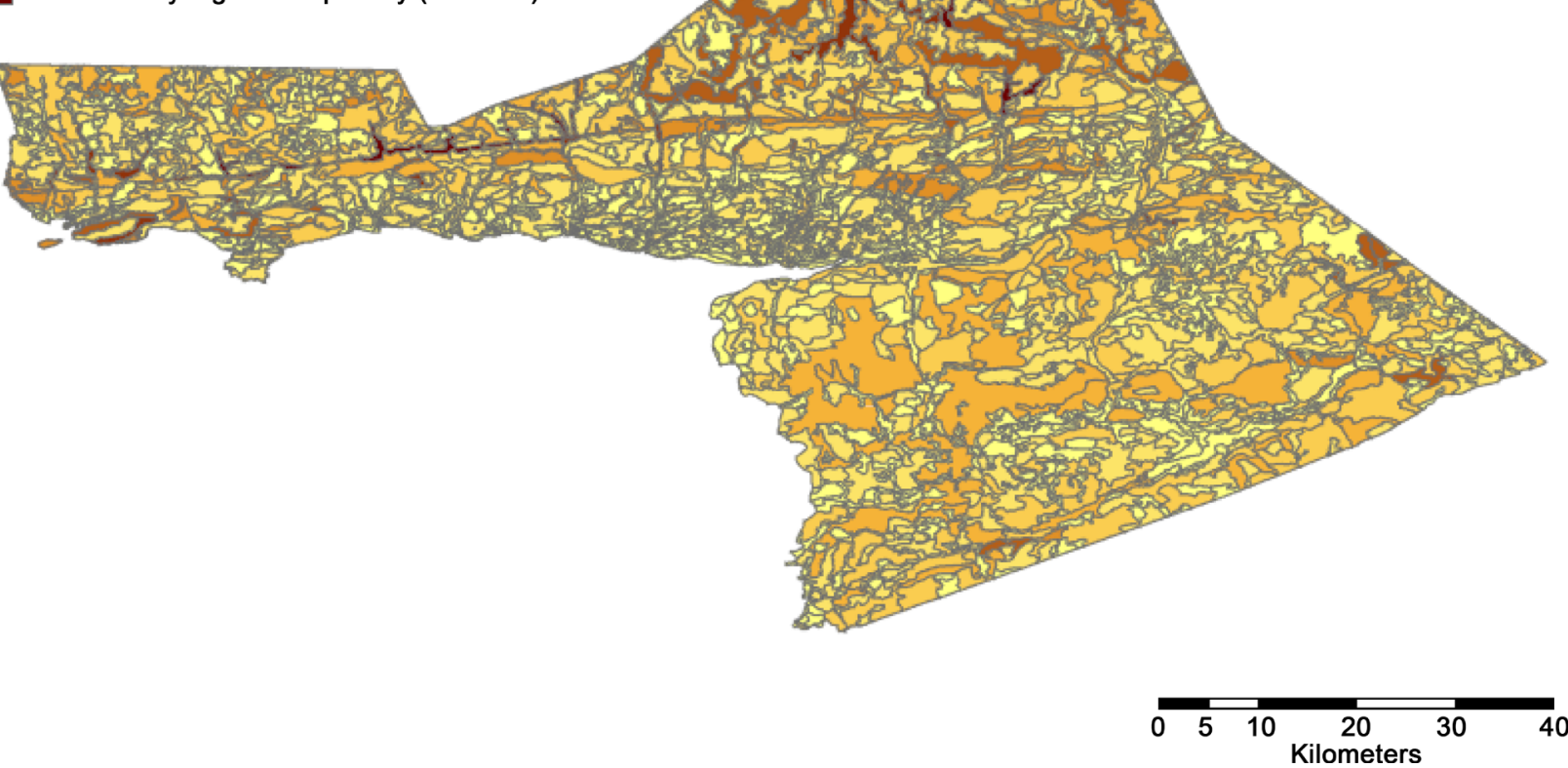

Figure 8. Mosaic of preliminary estimates of spatially-explicit soil erosion susceptibility for Colchester County, Nova Scotia (which contains the North River watershed). Classification categories pertain to Class $1=$ No susceptibility (light yellow); Class 2 = Very low susceptibility (yellow/orange); Class 3 = Low susceptibility (light orange); Class $4=$ Medium to low susceptibility (medium orange); Class 5 = Medium susceptibility (dark orange); Class $6=$ Medium to high susceptibility (orange/red); Class $7=$ High susceptibility (red); and Class $8=$ Very high susceptibility (dark red). Actual soil loss rates for these categories are provided in Table 1. Source: [48]. Much of the Salmon River watershed (lower left, south-east corner of the County) has erosion rankings of Classes 1 to 3 (i.e. No to Low susceptibilities), whereas portions of the North River watershed (upper, north-central portion of the County) has erosion rankings of Classes 5 to 7 (i.e. Medium to High susceptibilities). 
those months of $50 \mathrm{~mm}$ ) (Environment Canada, online meteorological data). The watershed, and particularly the terminus coastal town of Truro-Bible Hill where it joins with the Salmon River, have experienced substantial flooding [45] [46], serious enough in the last half decade to garner extensive national press and necessitating the consideration of mitigation measures. Most significantly, the recent generation of a province-wide watershed assessment framework [49] identified several of the watersheds in Colchester County, including that of North River, as being those ranked with the highest proportion of erodible soil in relation to land-use, and consequently the highest and second-highest threat to both surface erosion and ensuing water quality.

\section{Soil Erosion Model}

The model used in this project is based on the Revised Universal Soil Loss Equation (RUSLE) [2] [50] [51]. The RUSLE model includes the parameters of $\mathrm{R}$ (rainfall), K (soil erodibility), L (slope length), S (slope steepness), C (cover management), and sometimes $\mathrm{P}$ (support practices; not used in the present case).

The climatic factor $(\mathrm{R})$ refers to the mean annual summation of individual storm erosion index values and is related to the total kinetic energy in maximum $30 \mathrm{mi}-$ nutes rainfall intensity [52]. The $\mathrm{R}$ factor was calculated using the standard equation:

$$
R=\frac{1}{n} \sum_{j=1}^{n}\left[\sum_{k=1}^{m}(E)\left(I_{30}\right)_{k}\right]
$$

where $E=$ total storm kinetic energy $(\mathrm{MJ} / \mathrm{ha}) ; I_{30}=$ the maximum 30 mins rainfall intensity; $j=$ the index for the number of years used to compute the average; $\mathrm{k}=$ the index of the number of storms in each year; $\mathrm{n}=$ the number of years to obtain average; and $\mathrm{m}=$ the number of storms in each year. Decadal-long patterns of monthly rainfall data from four Environment Canada meteorological stations, representing the major physiographic zones in Colchester County [53], were used to create an R factor map for the entire county [48] (Figure 9). This was then made specific for the North River watershed through clipping to generate a map wherein spatially-explicit soil erosion rates were grouped into three categories characteristic of Atlantic Canada [54]: 11 - 22 tons ha $^{-1}$ year $^{-1}$ (Moderate), 22 - 33 tons ha ${ }^{-1}$ year $^{-1}$ (High), and 33 - 44 tons ha ${ }^{-1}$ year $^{-1}$ (Severe).

The soil erodibility factor $(\mathrm{K})$ measures the susceptibility of soil particles to transportation and detachment by the impact of rainfall. In general, large soil particles are more difficult to be moved because they require more energy to be entrained. The least resistant soil particles are silts and very fine sands. Soil with a high content of base minerals are more stable as these contribute to the chemical bonding of the aggregates. Increases in moisture content of a soil weaken aggregates because due to reducing cohesiveness. Soils with less than two percent organic carbon, equivalent to about 3.5 percent organic matter can be considered as erodible. Soil erodibility decreases linearly with increasing organic matter over the range of 0 to 10 percent [55]. The soils of Colchester County represent 6 of the 9 orders defined in the Canadian system of soil classification, 


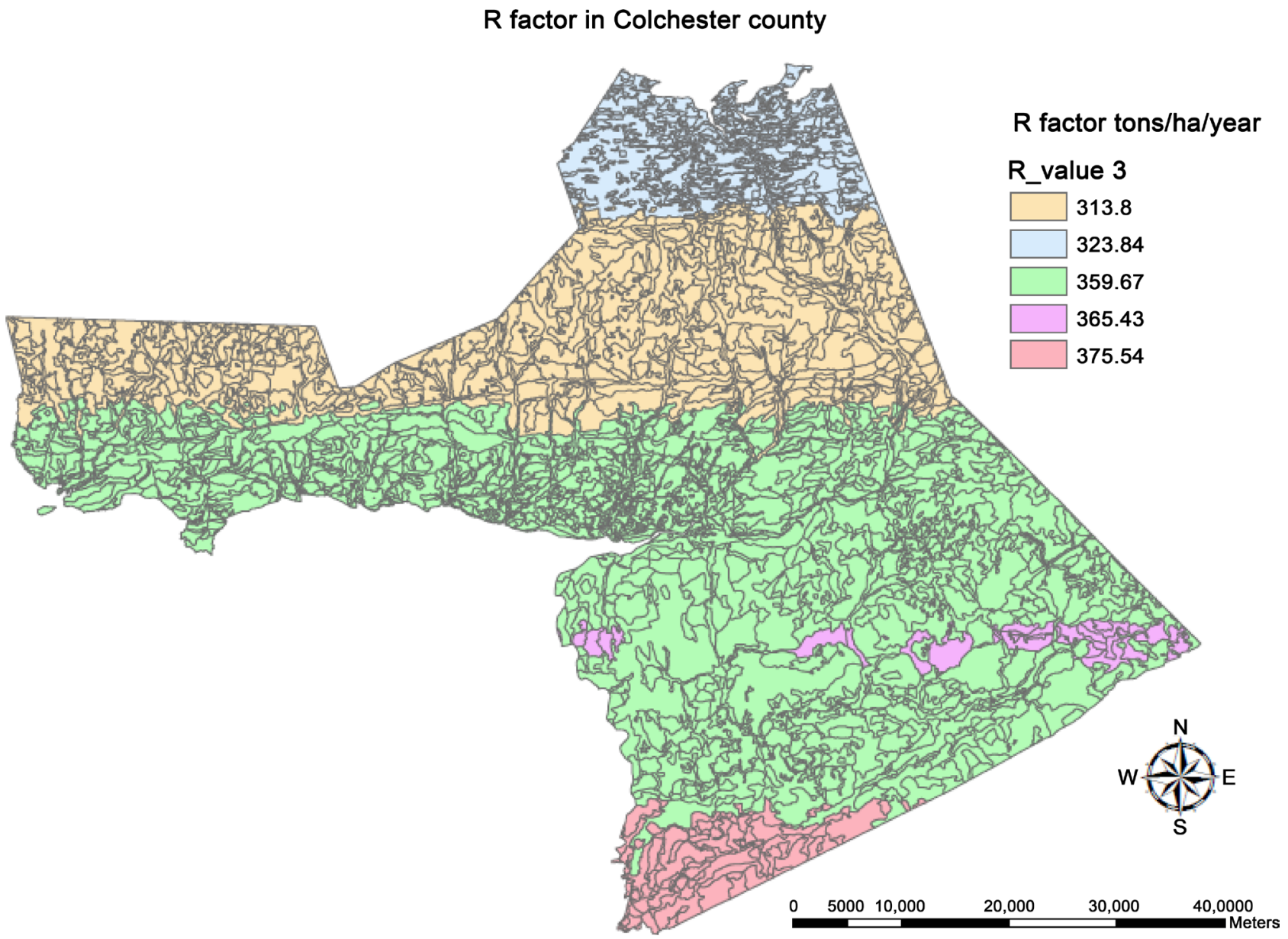

Figure 9. R factor map for Colchester County, Nova Scotia. Source: [48].

and can be divided into 24 soil more specific associations depending on parent material, landform, location, and texture [47]. Therefore, the $\mathrm{K}$ factor for each soil association was calculated using the soil erodibility nomograph based on the percent of silt, very find sand, total sand, organic matter, soil structure, and permeability of the soil [56]. The $\mathrm{K}$ values of some soils were difficult to determine from the nomograph. Because of this, the standard equation for calculating $K$ value [53] was used, based on the percent of silt, clay and sand, soil structure, organic matter, and permeability data existing for all the 24 soil associations [47]:

$$
100 \mathrm{~K}=2.1 \mathrm{M}^{1.14}\left(10^{-4}\right)(12 * \mathrm{a})+3.25(\mathrm{~b} * 2)+2.5(\mathrm{c} * 3)
$$

where $M=(\text { percent silt + very fine sand })^{\star}(100$-percent clay $) ; a=$ percent of organic matter; $b=$ the soil structure code used in soil classification; and $c=$ the permeability class. A spatially-explicit $\mathrm{K}$ factor map was created for the North River watershed using GIS.

Soil erosion is expected to increase with increases in slope steepness due to the relevant increases in velocity and volume of surface runoff. The $S$ factor was derived from a Digital Elevation Model (DEM) created with North River watershed 
(Figure 10) based on the contour line map, elevation spot map, and the watershed boundary. From these, a hydrology map was derived for the watershed.

Projected changes in precipitation amounts, and therefore predicted potential soil erosivity, were obtained from the Canadian Regional Climate Model (CRCM) [57] [58], as applied to Nova Scotia, Canada (France and Aitchison, in prep). In particular, for our study site of the North River watershed, we estimated the influence of regional climate change (i.e. increasing precipitation) on soil erosivity by running the integrated (GIS, RUSLE) model with both a 5 and a $10 \%$ increase in the $\mathrm{R}$ factor projected for the region. These two scenarios are thought to represent first, an immediate and very modest degree of climate change, and second, a realistic amount of further change for the near future period of the next 25 years in Nova Scotia (France and Aitchison, in prep).

Reviews of the effectiveness of buffer strips generally converge with an agreement that vegetated riparian zones of a minimum of $30 \mathrm{~m}$ width are generally

\section{DEM for North River Watershed}

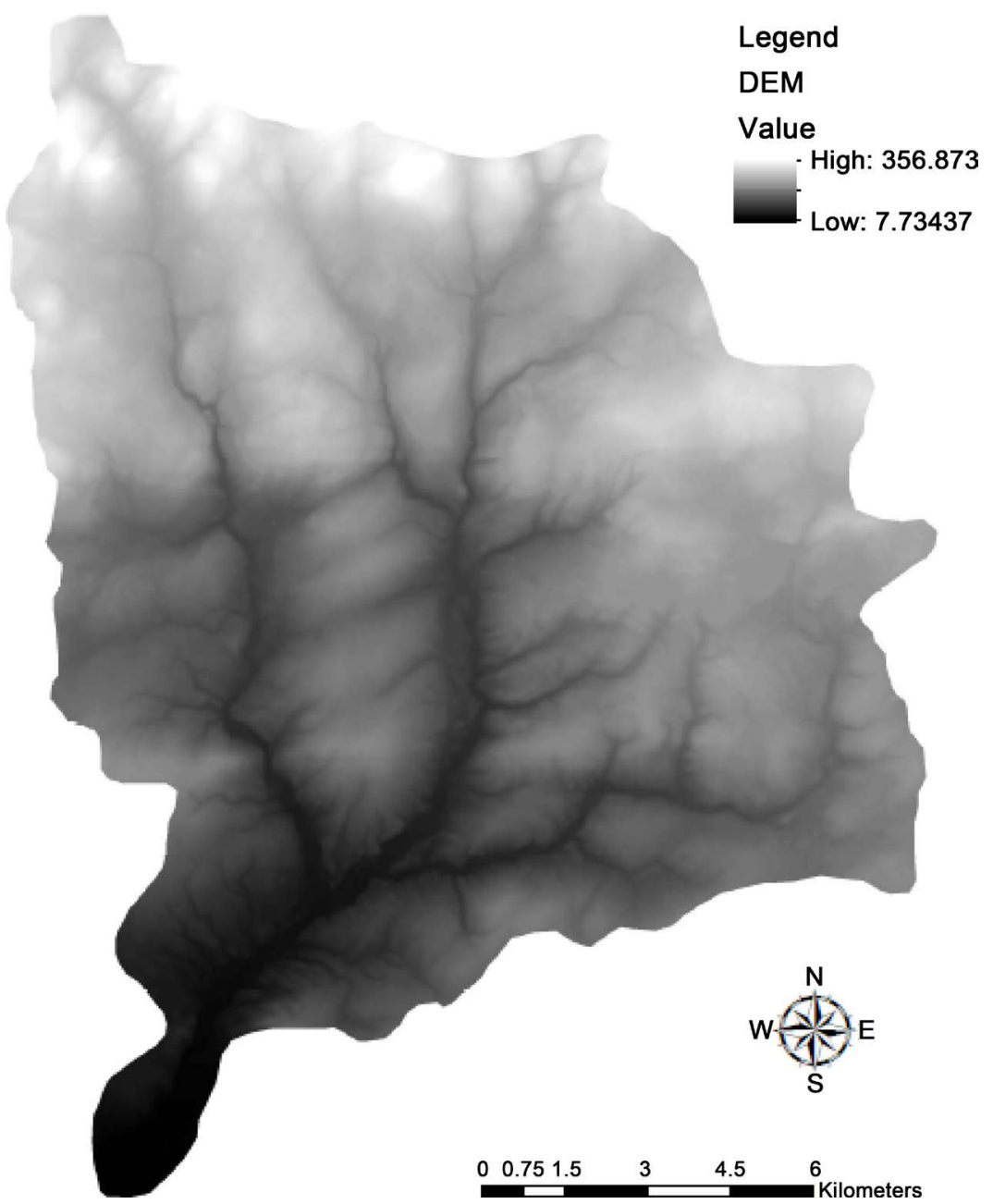

Figure 10. Digital elevation map (DEM) created for the North River Watershed. Shading reflects terrain roughness. 
adequate to maintain water quality [21] [14] [26]. Ontario's recommended guidelines for riparian buffer strip widths (termed "areas of concern") are based on preventing the transport of eroded soil in relation to surface slope: $30 \mathrm{~m}$ for slopes $<15 \%, 50 \mathrm{~m}$ for slopes of $16 \%$ to $30 \%, 70 \mathrm{~m}$ for slopes of $31 \%$ to $45 \%$, and $90 \mathrm{~m}$ for slopes $>46 \%$ [59] [60]. Because differences exist in buffer strip management in terms of recommendations for either consistent [26], or in the case of Ontario, variable, widths, we estimated the influence of buffer strip BMPs (i.e. increasing widths) on soil erosivity in the North River watershed in two ways: first, by running the integrated (GIS, RUSLE) model for buffer strips of consistent widths of either $30,50,70$ or $90 \mathrm{~m}$; and second, by running the model for variable width buffers, based on the Ontario framework, as determined in relation to DEM-calculated riparian slopes, as in France et al. [15]. In both cases, it was assumed that the modeled buffer strips would operate at optimal functionality in terms of eliminating all soil transport, a result consistent with measurements of erosion plumes made in Canadian watersheds of similar topography [17].

\section{Results}

\section{Existing Soil Erosion}

GIS analysis of the North River watershed revealed the spatial variability of estimated soil erosion (Figure 11 top panel). The most abundant erosion category was Moderate (Table 2). The total amount of erosion integrated for the entire watershed was estimated to be 465,285 tons $\mathrm{yr}^{-1}$ or 20.9 tons $\mathrm{ha}^{-1} \mathrm{yr}^{-1}$ (Table 3).

\section{Influence of Climate Change}

Increasing the precipitation $\mathrm{R}$ factor in the RUSLE model by $5 \%$, thereby representing a scenario of realistically expected immediate and very modest climate change, altered the spatial distribution of estimated erosion in the North River watershed (Figure 11 middle panel). Compared to existing conditions, the Moderate erosion category decreased and the High and Severe erosion categories increased (Table 2). There was an overall $4.9 \%$ increase in total watershed erosion to 488,190 tons $\mathrm{yr}^{-1}$ or 21.9 tons $\mathrm{ha}^{-1} \mathrm{yr}^{-1}$ (Table 3).

Increasing the R factor in the RUSLE model by $10 \%$, thereby representing a realistic climate change scenario for the near future, further altered the spatial distribution of estimated erosion in the North River watershed (Figure 11 bottom panel). Compared to existing conditions, the Moderate erosion category decreased, and the High and Severe erosion categories increased (Table 2). There was an overall $9.9 \%$ increase in watershed erosion to 511,437 tons $\mathrm{yr}^{-1}$ or 23.0 tons $\mathrm{ha}^{-1} \mathrm{yr}^{-1}$ (Table 3).

\section{Influence of Riparian Buffer Strips}

The moderate erosion rates calculated for existing conditions for the North River watershed are partially a reflection of its shallow terrain. Even given this, the BMP of implementing riparian buffer strips of consistent width was found to substantially reduce predicted erosion rates (Table 3). These results correspond 
to decreases in predicted total watershed erosion from existing conditions of $11 \%, 18 \%, 25 \%$ and $32 \%$ for buffer strip consistent-widths, respectively, of $30 \mathrm{~m}$,

\section{Soil Erosion Class Map for Northriver Watershed}

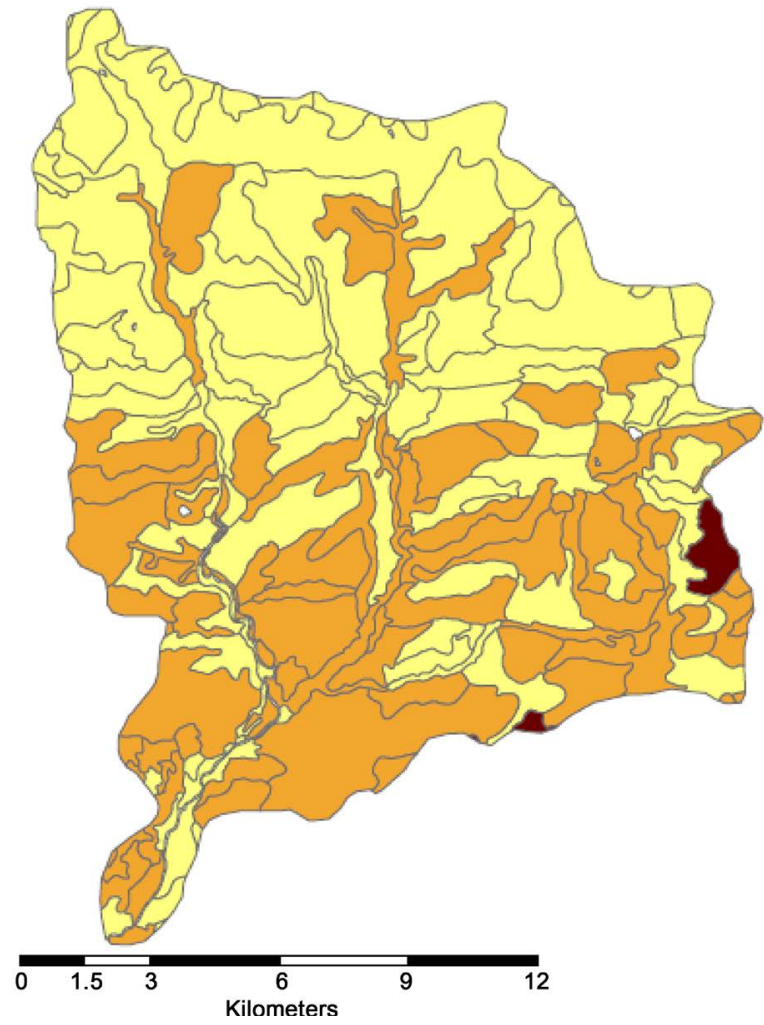

North_River_soils

Soil_ero 2

$15.87828-22.00000$

$22.00001-33.00000$

$33.00001-37.22585$

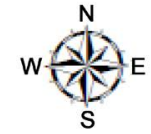

Soil Erosion Class Map for Northriver Watershed R 5\%

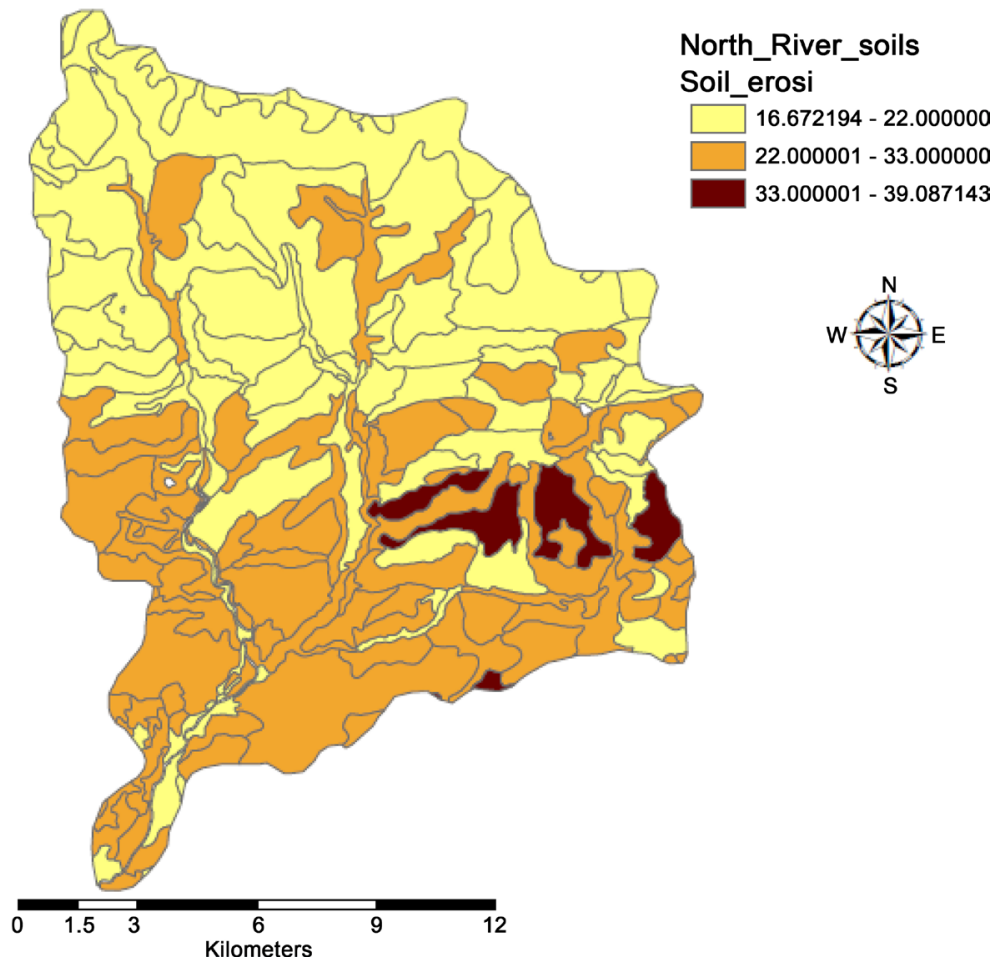




\section{Soil Erosion Class Map for Northriver Watershed R 10\%}

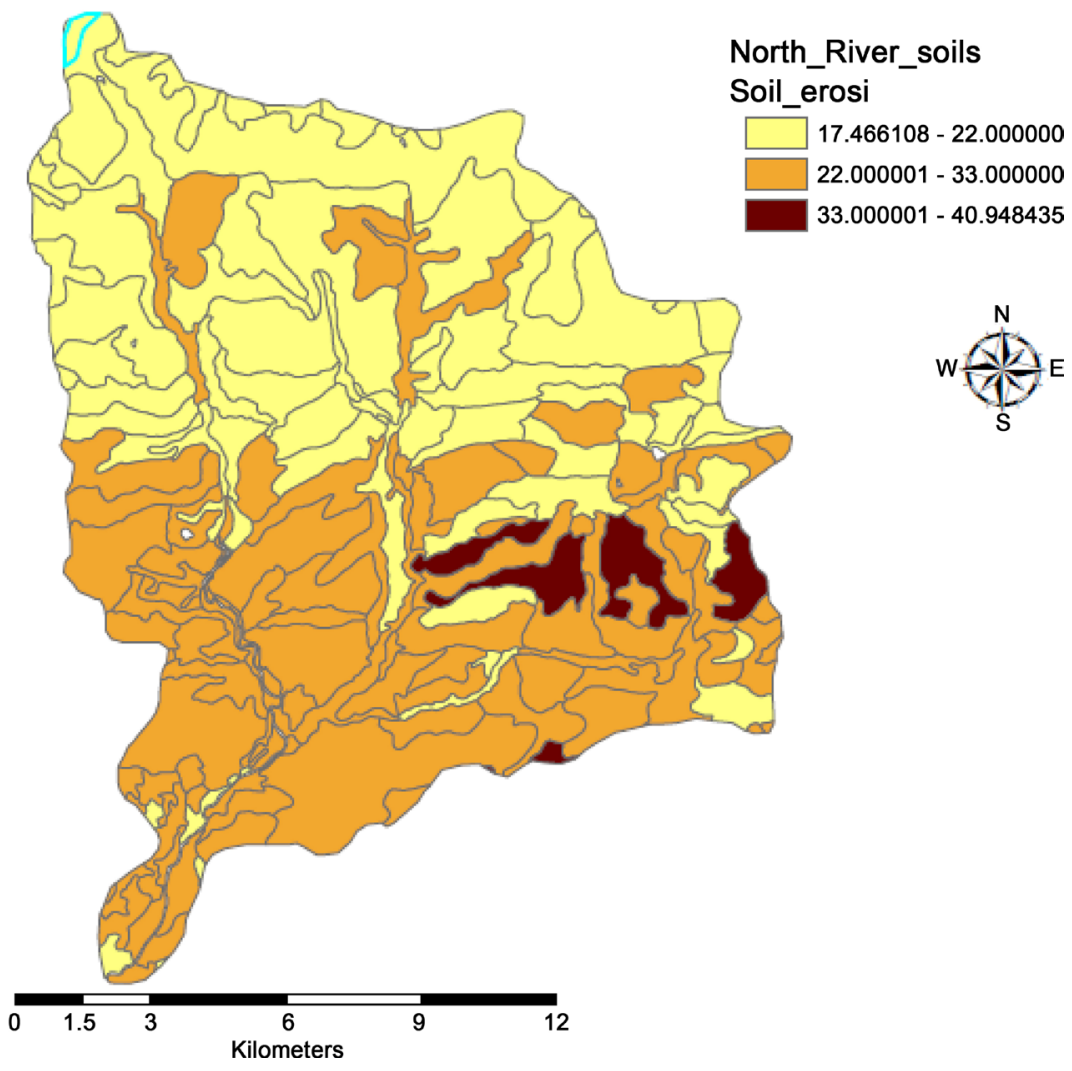

Figure 11. Spatially-explicit estimates of soil erosion classifications for Atlantic Canada from [54] applied to the North River watershed, Colchester County, Nova Scotia. Light yellow = "Moderate" or 11 (lowest observed rate 17) -22 tons $\mathrm{ha}^{-1} \mathrm{yr}^{-1}$ mid-tone orange = "High" or $22-33$ tons ha $^{-1} \mathrm{yr}^{-1}$, dark red = "Severe" or >33 (highest rate observed 41) tons $\mathrm{ha}^{-1} \mathrm{yr}^{-1}$ for the North River watershed, Colchester County, Nova Scotia under existing conditions (upper panel), and then projected climate change increases in annual precipitation of $5 \%$ (middle panel), and $10 \%$ (lower panel) for the spatial model (GIS, RUSLE) model.

Table 2. Extent (ha and proportion) of the North River watershed (Colchester Country, Nova Scotia) experiencing different categories of estimated erosion under existing conditions and modeled scenarios of climate change-induced increases in precipitation of $5 \%$ and $10 \%$.

\begin{tabular}{ccccccc}
\hline Erosion category & $\begin{array}{c}\text { Existing } \\
\text { ha }\end{array}$ & $\begin{array}{c}\text { Existing } \\
\%\end{array}$ & $\begin{array}{c}5 \% \text { increase } \\
\text { ha }\end{array}$ & $\begin{array}{c}5 \% \text { increase } \\
\%\end{array}$ & $\begin{array}{c}10 \% \text { increase } \\
\text { ha }\end{array}$ & $\begin{array}{c}10 \% \text { increase } \\
\%\end{array}$ \\
\hline Moderate & 12,525 & 56.4 & 11,528 & 51.9 & 10,757 & 48.5 \\
High & 9479 & 42.7 & 9872 & 44.5 & 10,644 & 47.9 \\
Severe & 194 & 0.9 & 798 & 3.6 & 798 & 3.6 \\
\hline
\end{tabular}

$50 \mathrm{~m}, 70 \mathrm{~m}$, and $90 \mathrm{~m}$. Application of variable-width buffer strips in concordance to riparian slopes (Figure 12) reduced erosion to 401,186 tons $\mathrm{yr}^{-1}$ or 18.3 tons $\mathrm{ha}^{-1} \mathrm{yr}^{-1}$, a decrease in predicted total watershed erosion of $12 \%$ from existing conditions. 
Table 3. Spatially-explicit estimates of erosion integrated for the entire watershed of the North River (Colchester County, Nova Scotia). Values indicate existing conditions and modeled scenarios of climate-induced increases of $5 \%$ and $10 \%$ in precipitation, and implementation of riparian buffer strips of consistent widths of $30 \mathrm{~m} 50 \mathrm{~m}, 70 \mathrm{~m}$, and $90 \mathrm{~m}$ as well as variable widths based on surface slope.

\begin{tabular}{ccc}
\hline & tons $\mathrm{yr}^{-1}$ & tons $\mathrm{ha}^{-1} \mathrm{yr}^{-1}$ \\
\hline Existing conditions & 465,285 & 20.9 \\
Climate change & & \\
$5 \%$ increase & 488,190 & 21.9 \\
$10 \%$ increase & 511,437 & 23.0 \\
Riparian buffer strips & & \\
$30 \mathrm{~m}$ & 413,697 & 18.6 \\
$50 \mathrm{~m}$ & 380,592 & 17.1 \\
$70 \mathrm{~m}$ & 348,459 & 15.7 \\
$90 \mathrm{~m}$ & 318,459 & 14.3 \\
Variable & 401,186 & 18.3 \\
\hline
\end{tabular}

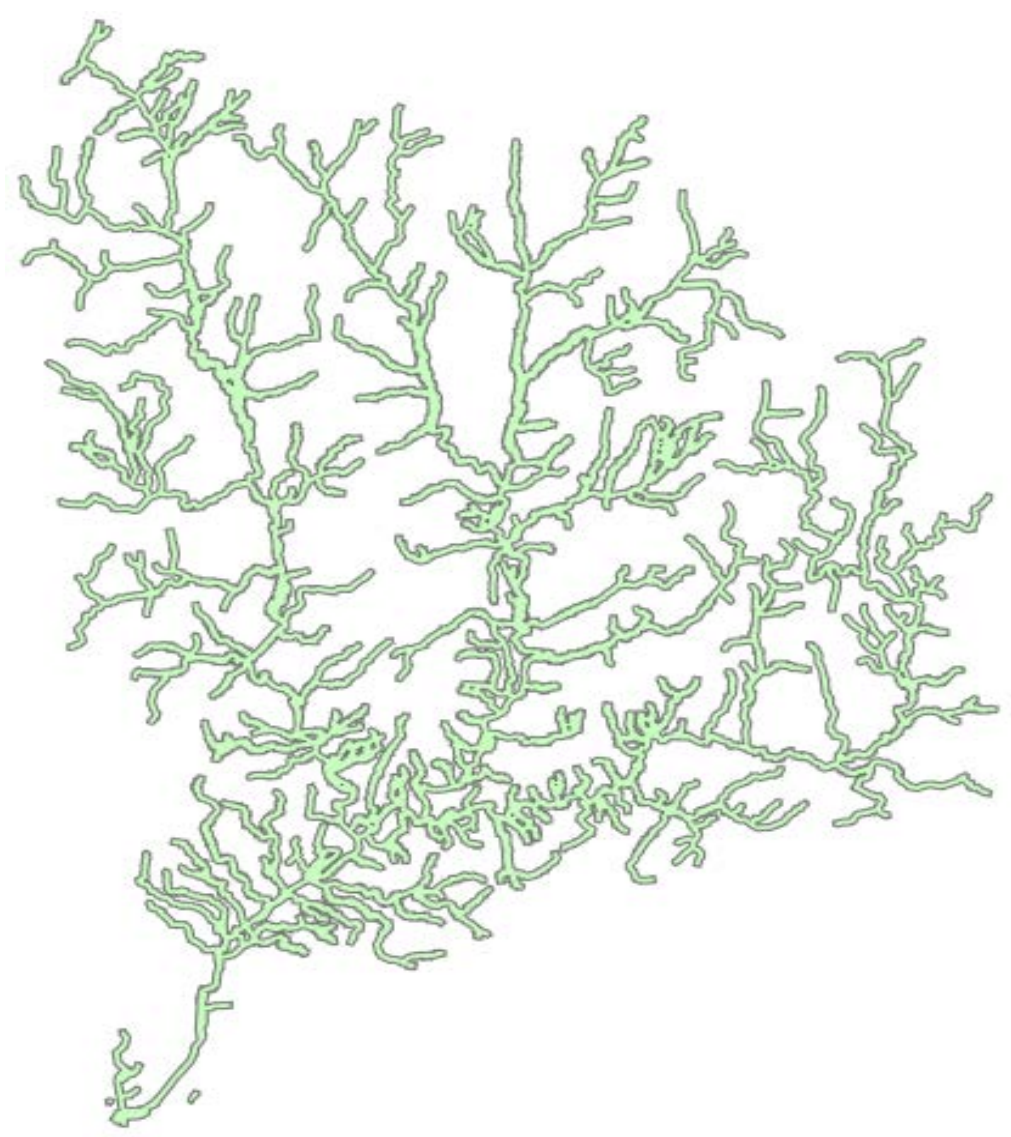

Figure 12. Network of streams in the North River watershed of Colchester County, Nova Scotia showing buffer strips of variable widths as determined in relation to surface topography (i.e. DEM-determined elevation gradients) of $30 \mathrm{~m}$ for riparian slopes $<15 \%, 50$ $\mathrm{m}$ for riparian slopes of $16 \%$ - 30\%, and $70 \mathrm{~m}$ for riparian slopes of $31 \%-45 \%$. 


\section{Discussion}

In comparison with erosion rates ranging from 7 to 70 tons $\mathrm{ha}^{-1} \mathrm{yr}^{-1}$ that have been determined for elsewhere in Atlantic Canada [48] [61] [62] [63] [64], the present findings suggest that the North River watershed experiences a moderate degree of erosion. The previous studies were conducted using either the RUSLE model or radio-cesium decay methods on specific field locations. The present study, in contrast, is the first to produce an estimate of soil erosion integrated for an entire watershed. That the watershed-level estimate compares well with site-specific radio-cesium measures made for another, nearby Nova Scotia location [54], gives credence to our belief in the accuracy in the GIS methodology used in the present study.

Our spatially-explicit, climate change modelling showed a near 1:1 concordance between forecasted projections of increased precipitation and consequent predicted increases in the extent of erosion for the North River watershed. Increasing precipitation by $5 \%$ resulted in increased total watershed erosion rates of $4.9 \%$, and increasing precipitation by $10 \%$ corresponded to a $9.9 \%$ increase in total watershed erosion. Other, non-spatially-explicit models have shown a wider range of predicted increases in soil erosion due to climate change. For example, Pruski and Nearing [6] found that each $1 \%$ increase in precipitation induced either a $0.85 \%, 2.38 \%$, and $1.66 \%$ increase in soil erosion for three simulated climate change scenarios and landscape typologies, for an average increase of $1.7 \%$ [7]. They believed that such greater-than-unity increases in erosion from elevated precipitation were due to the non-proportional influence of raindrops on interrill erosion, as consistent with the RUSLE model [30], although changes in vegetation patterns could certainly have played a moderating role as well.

Our modelled predictions are in agreement with an extensive literature on the functional benefits of riparian buffer strips, including Vaidya et al. [37], who found progressive protection of water quality for streams in Nova Scotia in relation to increases in the of buffer widths of intact forest.

\section{Land-Use Management Implications}

Essential for sustainable resource management is the requirement to compare the influences of realized or predicted changes in climate and of land-use management on watershed erosion in concert. For example, modification of vegetative cover has been found to either mitigate [7] [8] [65] or have no effect [12] on climate change-induced alterations in erosion. The present study suggests that implementation of buffer strips of a consistent width of $30 \mathrm{~m}$ would be adequate to negate the higher erosion rates predicted for the near future scenario of increased precipitation over the next 25 years for a Nova Scotia watershed. Assuming and extending the 1:1 concordance between projected precipitation and estimated soil erosion for this particular watershed for the more distant future of the next quarter century (as predicted from the climate change models [66]), suggests that the $25 \%$ increase in soil erosion over this extended period could be offset only by expanding the protective buffer strip to a consistent width of $70 \mathrm{~m}$. 
The question arises of whether a land-use strategy of applying buffer strips should be based on the heuristically appealing variable-widths in relation to riparian slope [67] [15] [22], or rather on the logistically easier to apply and to enforce consistent-widths [68] [26]. The present results for a single Nova Scotia watershed characterized by low-terrain showed that ascription of a consistent buffer strip width of $30 \mathrm{~m}$ reduced predicted erosion rates to a magnitude comparable to that of applying variable-width buffer strips in relation to riparian slope (i.e. by $11 \%$ to $12 \%$ ).

Notwithstanding the reality of economic costs of $\$ 70 \mathrm{ha}^{-1} \mathrm{yr}^{-1}$ for ameliorative field management ensuing to Atlantic Canadian farmers in consequence of soil losses of over 20 tons $\mathrm{ha}^{-1} \mathrm{yr}^{-1}$ [54], there may of course be potential economic tradeoffs when watershed BMPs, such as buffer strips [24], are proscribed. It is understandable that concerns exist among land-use managers about the extent of resources that might be "locked up" in such buffer strip reserves. However, several Canadian GIS studies have shown that these concerns may be exaggerated, at least for non-mountainous areas [15] [26]. The present study suggests that expanding protective buffer strips from the legal requirement of $30 \mathrm{~m}$ to an increased width of $70 \mathrm{~m}$ will be needed in order to offset projected increases of $25 \%$ in soil erosion due to regional climate change over the next half century. Adopting such a mitigating management scheme would subsume $19 \%$ of the terrestrial area of the study watershed, and thus will consequent reductions in the amount of land available for agricultural production and timber harvest. Maintaining the equivalent degree of environmental protection as presently exists in the face of future climate change will therefore result in economic loses to the resource sector in this particular watershed. As has been frequently described in the popular press in relation to climate-proofing cities, the present findings represent yet another example of how adapting to climate change will come at a cost.

\section{Acknowledgements}

This research was funded by an Agriculture and Agri-Food Canada Technical Development Grant.

\section{References}

[1] Jones, J.A. (2011) Hydrologic Responses to Climate Change: Considering Geographic Context and Alternative Hypotheses. Hydrological Processes, 25, 1996-2000. https://doi.org/10.1002/hyp.8004

[2] Tahiri, M., Tabyaaoui, H., Tahiri, A., El Hadi, H., El Hammichi, F. and Achab, M. (2016) Modelling Soil Erosion and Sedimentation in the Oude Haricha Sub-Basin (Tahaddart Watershed, Western Rif, Morocco): Risk Assessment. Journal of Geoscience and Environmental Protection, 4, 107-119. https://doi.org/10.4236/gep.2016.41013

[3] Wu, F., Zhan, J., Su, H., Yan, H. and Ma, E. (2015) Scenario-Based Impact Assessment of Land Use/Cover and Climate Changes on Watershed Hydrology in Heihe 
River Basin of Northwest China. Advances in Meteorology, 2015, Article ID 410198. https://doi.org/10.1155/2015/410198

[4] Rowshon, M.K., Mabaruk, M.M., Marriott, M.J., Amin, M., Ashan, A. and Loh, E.W. (2014) Geospatial Water Quality Assessment System for the Sg. Buloh River Basin in Malaysia. International Journal of Water, 8, 401-421. https://doi.org/10.1504/IJW.2014.065795

[5] Nearing, M.A. (2001) Potential Changes in Rainfall Erosivity in the U.S. with Climate Change during the $21^{\text {st }}$ Century. Journal of Soil and Water Conservation, 56, 229-232.

[6] Pruski, F.F. and Nearing, M.A. (2002) Runoff and Soil-Loss Responses to Changes in Precipitation: A Computer Simulation Study. Journal of Soil and Water Conservation, 57, 7-16.

[7] Nearing, M.A., Pruski, F.F. and O’Neal, M.R. (2004) Expected Climate Change Impacts on Soil Erosion Rates: A Review. Journal of Soil and Water Conservation, 59, 43-49.

[8] Hatfield, J.L. and Prueger, J.H. (2004) Impacts of Changing Precipitation Patterns on Water Quality. Journal of Soil and Water Quality, 59, 51-58.

[9] Bussi, G., Francis, F., Horel, E., Lopez-Tarazon, J. and Batalla, R.J. (2014) Modelling the Impact of Climate Change on Sediment Yield in a Highly Erodible Mediterranean Catchment. Journal of Soils and Sediments, 14, 1921-1937. https://doi.org/10.1007/s11368-014-0956-7

[10] France, R., Peters, R. and McCabe, L. (1998) Spatial Relationships among Boreal Riparian Trees, Litterfall and Soil Erosion Potential with Reference to Buffer Strip Management and Coldwater Fisheries. Annales Botanici Fennici, 35, 1-9.

[11] France, R.L. and Pardy, G. (2018) Spatially-Explicit, Exposure-Based Assessment of Surface Water Vulnerability from Land Use Threats for Time-Efficient and Cost-Effective Watershed Development Planning. Journal of Geoscience and Environmental Protection, 6, 35-55.

[12] Blais, J.M., France, R.L., Kimpe, L.E. and Cornett, R.J. (1998) Climatic Changes in Northwestern Ontario Have Had a Greater Effect on Erosion and Sediment Accumulation than Logging and Fire: Evidence from ${ }^{210} \mathrm{~Pb}$ Chronology in Lake Sediments. Biogeochemistry, 43, 235-252. https://doi.org/10.1023/A:1006065109925

[13] Pusey, B.J. and Arthington, A.H. (2003) Importance of the Riparian Zone to the Conservation and Management of Freshwater Fish: A Review. Marine and Freshwater Research, 54, 1-16. https://doi.org/10.1071/MF02041

[14] Zhang, X., Liu, X., Zhang, M., Dahlgren, R.A. and Eitzel, M. (2010) A Review of Vegetated Buffers and a Meta-Analysis of Their Mitigation Efficacy in Reducing Nonpoint Source Pollution. Journal of Environmental Quality, 39, 76-84. https://doi.org/10.2134/jeq2008.0496

[15] France, R., Felkner, J.S., Flaxman, M. and Rempel, R. (2002) Spatial Investigation of Applying Ontario's Timber Management Guidelines: GIS Analysis for Riparian Areas of Concern. In: France, R., Ed., Handbook of Water Sensitive Planning and Design, CRC Press, Cambridge, 601-613. https://doi.org/10.1201/9781420032420.ch2.14

[16] Steedman, R.J. and France, R.L. (2000) Origin and Transport of Aeolian Sediment from New Clearcuts into Boreal Lakes, Northwestern Ontario, Canada. Water, Air and Soil Pollution, 122, 139-152. https://doi.org/10.1023/A:1005235604087

[17] France, R. (2002) Factors Influencing Sediment Transport from Logging Roads near 
Boreal Trout Lakes (Ontario, Canada). In: France, R., Ed., Handbook of Water Sensitive Planning and Design, CRC Press, Cambridge, 635-645. https://doi.org/10.1201/9781420032420.ch2.16

[18] O’Laughlin, J. and Belt, G.H. (1995) Functional Approaches to Riparian Buffer Strip Design. Journal of Forestry, 93, 29-32.

[19] Correll, D.L. (2005) Principles of Planning and Establishment of Buffer Zones. Ecological Engineering, 24, 433-439. https://doi.org/10.1016/j.ecoleng.2005.01.007

[20] Richardson, J.S., Naiman, R.J. and Bisson, P.A. (2012) How Did Fixed-Width Buffers Become Standard Practice for Protecting Freshwaters and Their Riparian Areas from Forest Harvest Practices? Freshwater Science, 31, 232-238. https://doi.org/10.1899/11-031.1

[21] Lee, P., Smyth, C. and Boutin, S. (2004) Quantitiative Review of Riparian Buffer Strip Width Guidelines from Canada and the United States. Journal of Environmental Management, 70, 165-180. https://doi.org/10.1016/j.jenvman.2003.11.009

[22] Creed, I.F., Sass, G.Z., Wolniewicz, M.B. and Devito, K.J. (2008) Incorporating Hydrologic Dynamics into Buffer Strip Design on the Sub-Humid Boreal Plain of Alberta. Forest Ecology and Management, 256, 1984-1994.

https://doi.org/10.1016/j.foreco.2008.07.021

[23] Island Nature Trust (2005) Beneficial Management Practices for Riparian Zones in Atlantic Canada. Agriculture and Agri-Food Canada, Ottawa.

[24] Xu, Q., Clark, S., Asiedu, S., Smutka, L. and Lewis, R. (2011) Benefits and Costs of Species Diversity and the Formation of Riparian Buffer Zones in Prince Edward Island in Canada. Nova Scotia Agricultural College, Truro.

[25] Rideout, E. (2012) Setbacks and Vegetated Buffers in Nova Scotia: A Review and Analysis of Current Practice and Management Options. Hydrologic Systems Research Group, Dalhousie Unversity, Halifax.

[26] Stoffyn-Egli, P. and Duinker, P.N. (2013) An Ecological Approach to Riparian-Buffer Definition, and Implications for Timber Harvests in Nova Scotia, Canada. Journal of Sustainable Development, 6, 111-134. https://doi.org/10.5539/jsd.v6n12p111

[27] Capron, S.J., Chambers, L.E., MacNally, R., Naiman, R.J. and Davies, P. (2013) Riparian Ecosystems in the $21^{\text {st }}$ Century: Hotspots for Climate Change Adaptation? Ecosystems, 16, 359-381. https://doi.org/10.1007/s10021-013-9656-1

[28] Williams, J., Nearing, M., Nicks, A., Skidmore, E. and Valentin, C. (1996) Using Soil Erosion Models for Global Change Studies. Journal of Soil and Water Conservation, 51, 381-385.

[29] Pruski, F.F. and Nearing, M.A. (2002) Climate-Induced Changes in Erosion during the $21^{\text {st }}$ Century for Eight U.S. Locations. Water Resources Research, 38, 23-35. https://doi.org/10.1029/2001WR000493

[30] Kertesz, A. (1993) Application of GIS Methods in Soil Erosion Modelling. Computers, Environment and Urban Systems, 17, 233-238. https://doi.org/10.1016/0198-9715(93)90018-Z

[31] Jabber, M.J. (2003) Application of GIS to Estimate Soil Erosion Using RUSLE. Geo-Spatial Information Science, 6, 34-37. https://doi.org/10.1007/BF02826699

[32] Mellerowicz, K.T., Ress, H.W., Chow, T.L. and Ghanem, I. (1994) Soil Conservation Planning at the Watershed Level Using the Universal Soil Loss Equation with GIS and Microcomputer Technologies: A Case Study. Journal of Soil and Water Con- 
servation, 49, 194-200.

[33] Lufafa, A., Tenywa, M.M., Isabirye, M., Majaliwa, M.J. and Woomer, P.L. (2003) Prediction of Soil Erosion in a Lake Victoria Basin Catchment Using a GIS-Based Universal Soil Loss Model. Agricultural Systems, 76, 883-894. https://doi.org/10.1016/S0308-521X(02)00012-4

[34] Parveen, R. and Kumar, U. (2012) Integrated Approach of Universal Soil Loss Equation (USLE) and Geographical Information System (GIS) for Soil Loss Risk Assessment in Upper South Koel Basin, Jharkhand. Journal of Geographic Information Systems, 4, 23-34. https://doi.org/10.4236/jgis.2012.46061

[35] Martin, C.W. and Hornbeck, J.W. (1994) Logging in New England Need Not Cause Sedimentation of Streams. Northern Journal of Applied Forestry, 11, 17-23.

[36] Mitchell, F. (2002) Shoreline Buffers: Protecting Water Quality and Biological Diversity (New Hampshire). In: France, R., Ed., Handbook of Water Sensitive Planning and Design, CRC Press, Cambridge, 361-377.

[37] Vaidya, O.C., Smith, T.P., Fernand, H. and Leek, N.R. (2008) Forestry Best Management Practices: Evaluation of Alternate Streamside Management Zones on Stream Water Quality in Pockwock Lakes and Five Mile Lake Watersheds in Central Nova Scotia, Canada. Environmental Monitoring and Assessment, 137, 1-14. https://doi.org/10.1007/s10661-006-9370-y

[38] Cantwell, M.Y. (2002) The Effect of Spatial Location in Land-Water Interactions: A Comparison of Two Modeling Approaches to Support Watershed Planning (Newfoundland, Canada). In: France, R., Ed., Handbook of Water Sensitive Planning and Design, CRC Press, Cambridge, 577-599. https://doi.org/10.1201/9781420032420.ch2.13

[39] Schloss, J.A. (2002) GIS Watershed Mapping: Developing and Implementing a Watershed Natural Resources Inventory (New Hampshire). In: France, R., Ed., Handbook of Water Sensitive Planning and Design, CRC Press, Cambridge, 557-575. https://doi.org/10.1201/9781420032420.ch2.12

[40] Yang, Q., Chow, T.L., Rees, H.W. and Meng, F.R. (2008) Using a GIS and Digital Elevation Model to Assess the Effectiveness of Variable Grade Flow Diversion Terraces for Reducing Soil Erosion in Northwestern New Brunswick. Hydrological Processes, 23, 3271-3280.

[41] Yang, Q., Meng, F., Zhao, Z., Chow, T.L. and Benoy, G. (2009) Assessing the Impacts of Flow Diversion Terraces on Stream Water and Sediment Yields at a Watershed Level Using SWAT. Agriculture, Ecosystems and Environment, 132, 23-31. https://doi.org/10.1016/j.agee.2009.02.012

[42] Ahmad, H.M.N., Sinclair, A., Jamieson, R., Madani, A., Hebb, D., Havard, P. and Yirodoe, E.K. (2011) Modeling Sediment and Nitrogen Export from a Rural Watershed in Eastern Canada Using the Soil and Water Assessment Tool. Journal of Environmental Quality, 40, 1182-1194. https://doi.org/10.2134/jeq2010.0530

[43] Benoy, G.A., Sutherland, A.B., Culp, J.M. and Brond, R.B. (2012) Physical and Ecological Thresholds for Deposited Sediments in Streams in Agricultural Landscapes. Journal of Environmental Quality, 41, 31-40. https://doi.org/10.2134/jeq2010.0251

[44] Amon-Armah, F., Yirodoe, E.K., Ahmad, N.H.M., Hebb, D., Jamieson, R., Burton, D. and Madani, A. (2013) Effect of Nutrient Management Planning on Crop Yield, Nitrate Leaching and Sediment Loading in Thomas Brook Watershed. Environmental Management, 52, 1177-1191. https://doi.org/10.1007/s00267-013-0148-Z

[45] El-Sharif, A. and Hansen, D. (2001) Application of SWMM to the Flooding Prob- 
lem in Truro, Nova Scotia. Canadian Water Resources Journal, 26, 439-459. https://doi.org/10.4296/cwrj2604439

[46] Patton, A.S.M. (2005) A Study of the Hydrological Characteristics of the North and Salmon Rivers in Relations to Central Colchester County Flooding. M.Sc. Thesis, Dalhousie University, Truro.

[47] Webb, K.T., Thompson, R.L., Beke, G.J. and Nowland, J.L. (1991) Soils of Colchester Country, Nova Scotia. Report No. 19, Nova Scotia Soil Survey, Agriculture Canada.

[48] Zhang, C. (2012) Soil Erosion Modeling Using GIS in Colchester County. Honours Thesis, Nova Scotia Agricultural College, Truro.

[49] Sterling, S.M., Garroway, K., Guan, Y., Ambrose, S.M. and Horne, P. (2014) A New Watershed Assessment Framework for Nova Scotia: A High-Level, Integrated Approach for Regions without a Dense Network of Monitoring Stations. Journal of Hydrology, 519, 2596-2612. https://doi.org/10.1016/j.jhydrol.2014.07.063

[50] Renard, K.G., Foster, G.R., Yoder, D.C. and McCool, D.K. (1994) RUSLE Revisited: Status, Questions, Answers, and the Future. Journal of Soil and Water Conservation, 49, 213-220.

[51] Soil and Water Conservation Society (SWCS) (1995) RUSLE User Guide Revised Universal Soil Loss Equation Version 1.04. Ankeny, Iowa.

[52] Wischmeier, W. and Smith, D. (1965) Predicting Rainfall Erosion Losses from Cropland East of the Rocky Mountains: Guide for Selection of Practices for Soil and Water Conservation. U.S. Department of Agriculture Handbook No. 537.

[53] Wicklund, R.E. and Smith, G.R. (1948) Soil Survey of Colchester County Nova Scotia. Report No. 3, Nova Scotia Soil Survey, Experimental Farms Service, Dominion Department of Agriculture.

[54] Sheeran, M.D. (2000) Comparison of Observed and Calculated Annual Soil Losses for Prince Edward Island Using the Revised Universal Soil Loss Equation. M.Sc. Thesis, Dalhousie University, Halifax.

[55] Renard, R.G. and Freidmond, J.R. (1994) Using Monthly Precipitation Data to Estimate the R Factor in the Revised USLE. Journal of Hydrology, 157, 287-306. https://doi.org/10.1016/0022-1694(94)90110-4

[56] Tew, K. (1999) Production of Malaysian Soil Erodibility Nomograph in Relation to Soil Erosion Issues. VT Soil Erosion Research and Consultancy.

[57] Laprise, R., Caya, D., Giguere, G., Bergeron, H. and Cote, J.P. (1998) Climate and Climate Change in Western Canada as Simulated by the Canadian Regional Climate Model. Atmosphere and Oceans, 36, 119-167. https://doi.org/10.1080/07055900.1998.9649609

[58] Caya, D. and Laprise, R. (1999) A Semi-Implicit Semi-Lagrangian Regional Climate Model: The Canadian RCM. Monthly Weather Review, 127, 341-362. https://doi.org/10.1175/1520-0493(1999)127<0341:ASISLR>2.0.CO;2

[59] Ontario Ministry Natural Resources (1988) Timber Management Guidelines for Protection of Fish Habitat. ONMR, Toronto.

[60] Ontario Ministry Natural Resources (1991) Code of Practice for Timber Management Operations in Riparian Areas. ONMR, Toronto.

[61] Kachanoski, R.G. (1992) Evaluation of Soil Loss Rates under Different Soil and Cropping Practices in Prince Edward Island. Final Report, National Soil Conservation Program, Agriculture and Agri-Food Canada, Charlottetown. 
[62] Edwards, L. (1995) Rill Erosion Causes Massive Soil Loss in Spring from Prince Edward Island (PEI) Potato Lands. Agriculture and Agri-Food Canada, Charlottetown.

[63] Edwards, L., Richter, G., Bernsdorf, B., Schmidt, R. and Burney, J. (1998) Measurement of Rill Erosion by Snowmelt on Potato Fields under Rotation in Prince Edward Island (Canada). Canadian Journal of Soil Science, 78, 449-458. https://doi.org/10.4141/S97-053

[64] Jacobs, P. (1997) Best Management Practices Soil Conservation for Potato Production. PEI Department of Fisheries and Environment, PEI Department of Agriculture and Forestry, Environment Canada, and Agriculture and Agri-Food Canada, Charlottetown.

[65] De Munck, C.S., Hutchings, T.R. and Moffat, A.J. (2007) Impacts of Climate Change and Establishing a Vegetation Cover on Water Erosion of Contaminated Spoils for Two Contrasting United Kingdom Regional Climates: A Case Study Approach. Integrated Environmental Assessment and Management, 3, 443-455.

[66] Dayyani, S., Prasher, S.O., Madramootoo, C.A., Madani, A. and Lebel, S. (2010) Impact of Climate Change on Drainage Outflow and Water Quality in Eastern Canada. World Congress of the International Commission of Agriculture and Biosystems Engineering, Vol. 17, Québec City, 13-17 June 2010, 1-12.

[67] Haberstock, A.E., Nichols, H.G., DesMeules, M.P., Wright, J., Christensen, J.M. and Hudnut, D.H. (2000) Method to Identify Effective Riparian Buffer Widths for Atlantic Salmon Habitat Protection. Journal of the American Water Resources Association, 36, 11271-1286. https://doi.org/10.1111/j.1752-1688.2000.tb05726.x

[68] Luke, S.H., Luckai, N.J., Burke, J.M. and Prepas, E.E. (2008) Riparian Areas in the Canadian Boreal Forest and Linkages with Water Quality in Streams. Environmental Reviews, 15, 79-97. https://doi.org/10.1139/A07-001 